\title{
Physiological Response of European Hornbeam Leaves to Nitrogen Dioxide Stress and Self-recovery
}

\author{
Qianqian Sheng \\ Co-Innovation Center for Sustainable Forestry in Southern China, College of Landscape Architec- \\ ture, Nanjing Forestry University, Nanjing 210037, People's Republic of China \\ Zunling Zhu' ${ }^{\mathbf{1}}$ \\ Co-Innovation Center for Sustainable Forestry in Southern China, College of Landscape Architec- \\ ture, Nanjing Forestry University, Nanjing 210037, People's Republic of China; and College of Art \\ and Design, Nanjing Forestry University, Nanjing 210037, People's Republic of China
}

\begin{abstract}
Additional Index words. Carpinus betulus, chloroplast ultrastructure, photosynthesis, stomatal behavior
Abstract. Plant leaves absorb atmospheric nitrogen dioxide $\left(\mathrm{NO}_{2}\right)$ primarily via the stomata. Studies of changes in plant growth and physiology after exposure to $\mathrm{NO}_{2}$ are limited. Therefore, this study investigated the physiological response of Carpinus betulus (european hornbeam) chloroplasts after $\mathrm{NO}_{2}$ exposure using fumigation equipment that was able to control timing and record $\mathrm{NO}_{2}$ concentrations. The $\mathrm{NO}_{2}$ concentration was $6 \mu \mathrm{L} \cdot \mathrm{L}^{-1}$. Seven treatment durations $(0,1,6,12,24,48$, and 72 hours) were designed. After fumigation, plants recovered for 30 days under greenhouse conditions. The physiological response, stomatal behavior, thicknesses of palisade and spongy tissues, and chloroplast ultrastructure were measured. In the 48-hour and 72-hour $\mathrm{NO}_{2}$ treatment groups, the chloroplast contents and net photosynthesis rates of the leaves decreased, palisade and spongy tissues thickened, and chloroplast thylakoids swelled; however, the 1-hour $\mathrm{NO}_{2}$ treatment did not have a noticeable toxic effect on $C$. betulus leaves. After 30 days of recovery, the plants returned to their natural growth level by increasing the chloroplast content and enhancing net photosynthesis. Short durations and high concentrations of $\mathrm{NO}_{2}$ exposure had significantly negative impacts on the physiological response of $C$. betulus; however, this toxic effect of high $\mathrm{NO}_{2}$ concentrations on $C$. betulus can be recovered by restoration of unpolluted air. The results of this study may provide a scientific reference and an additional choice of plants species for the application of $\boldsymbol{C}$. betulus in functional gardening design and ecological green space construction.
\end{abstract}

As one of the most common pollutant gases and a major threat to ecosystems, $\mathrm{NO}_{2}$, which is a brown-red gas with a pungent odor, is an atmospheric pollutant that originates primarily from vehicle emissions, fuel burning in power plants, and industrial production of nitric acids (Chai et al., 2002). $\mathrm{NO}_{2}$ serves as a precursor of ozone and atmospheric particles, and it is an essential atmospheric pollutant for the formation of acid rain (Bermejo-Orduna et al., 2014; Rahmat et al., 2013). In recent decades, the emission of $\mathrm{NO}_{2}$ has increased in many countries worldwide (Frati et al., 2008; Munzi et al., 2009), particularly in China and other Asian countries (Hu et al., 2015; van der A et al., 2008). In China, the national concentration threshold for $\mathrm{NO}_{2}$ pollution is $0.0199 \mu \mathrm{L} \cdot \mathrm{L}^{-1}$, and the atmospheric concentration of $\mathrm{NO}_{2}$ near highways reaches 0.0255 $0.058 \mu \mathrm{L} \cdot \mathrm{L}^{-1}$ (Nanjing Environmental Protection Bureau, 2016). Furthermore, with the progression of urban industrialization and automation, the $\mathrm{NO}_{2}$ concentration may continue to increase (Munzi et al., 2009). Therefore, it is critical to determine ecologically and environmentally friendly methods to reduce atmospheric $\mathrm{NO}_{2}$ concentrations.

Received for publication 2 July 2018. Accepted for publication 30 Oct. 2018. This work was supported by The National Natural Science Foundation of China (31770752), Jiangsu Province Agricultural Science and Technology Independent Innovation Funds (CX (16)1005-4), Postgraduate Research \& Practice Innovation Program of Jiangsu Province, Jiangsu Province Engineering Technology Research Center Projects (BM2013478), Jiangsu Province Six Big Talent Peak Project (NY-029), and Fifth Stage Funded Research Projects of 333 in Jiangsu Province.

${ }^{1}$ Corresponding author. E-mail: zhuzunling@njfu.edu.cn.
Injury to plants is primarily due to the corrosive and high oxidative properties of $\mathrm{NO}_{2}$, which influence various physiological and biochemical processes after entering plants via the stomata ( $\mathrm{Lu}$ et al., 2002). $\mathrm{NO}_{2}$ can cause reductions in growth, and the amount of damage experienced by a plant varies according to different factors, such as the concentration and length of exposure, plant age, edaphic factors, light, and humidity. Symptoms are often divided into "visible" and "invisible" (or hidden) injuries, which comprise an overall reduction in growth but no obvious signs of visible damage (Wellburn, 1990) and mainly affect the physiological metabolism of plants.

Chlorophyll $(\mathrm{Chl})$ is the most important plant pigment because it has a crucial role in photosynthesis (Croft et al., 2017). Chen et al. (2010) performed $\mathrm{NO}_{2}$ fumigation of Cinnamomum camphora seedlings at low-volume fractions for $60 \mathrm{~d}$ and found that $4.0 \mu \mathrm{L} \cdot \mathrm{L}^{-1}$ of $\mathrm{NO}_{2}$ significantly decreased the $\mathrm{Chl}$ content in the leaves of seedlings. Changes in the leaf color that resulted in yellow spots or yellow leaves were attributable to the change in Chl content. Liu et al. (2015) found that Arabidopsis thaliana initiated stress-resistant protective mechanisms triggered by superoxide free radicals under $\mathrm{NO}_{2}$ stress. Hu et al. (2015) reported that the net photosynthesis of Populus alba $\times$ P. berolinensis hybrid leaves significantly decreased after 14 and $48 \mathrm{~h}$ of exposure to $4 \mu \mathrm{L} \cdot \mathrm{L}^{-1}$ of $\mathrm{NO}_{2}$, thus demonstrating that inhibition of photosynthesis may be responsible for the suppression of growth by $\mathrm{NO}_{2}$. Furukawa et al. (1984) found that exposure to 2 and $4 \mu \mathrm{L} \cdot \mathrm{L}^{-1}$ of $\mathrm{NO}_{2}$ for $2 \mathrm{~h}$ decreased the net photosynthesis rate by $20 \%$ and 
$90 \%$, respectively, but had no significant effect on reducing transpiration.

Ultrastructural changes associated with invisible injuries have often been linked to decreased transpiration and photosynthesis (Fink, 1988; Huttunen and Soikkeli, 1984), and some occurred in both mitochondria and chloroplasts. Fouryear-old Norway spruce trees (Picea abies) were fumigated with $1 \mu \mathrm{L} \cdot \mathrm{L}^{-1}$ of $\mathrm{NO}_{2}$ (low concentration) for 3 weeks, resulting in swollen thylakoids, decreased grana stacks, and enhanced starch contents compared with controls (Schiffgens-Gruber and Lütz, 1992). Mature bean (Phaseolus vulgaris) tissue was exposed to 1 and $2 \mu \mathrm{L} \cdot \mathrm{L}^{-1}$ of $\mathrm{NO}_{2}$ for 1 and $2 \mathrm{~h}$ and compared with similar untreated tissues; the $\mathrm{NO}_{2}$-exposed bean tissue showed swelling of the thylakoids within the chloroplasts but no extrachloroplastic damage, and the thylakoid swelling could be reversed by removing the pollutant from the air flow or changing the rate of gas flow within the tissue (Wellburn et al., 1972). Chaparro-Suarez et al. (2011) found that $\mathrm{NO}_{2}$ was not absorbed by plants when the stomata were closed, and that species-dependent differences in uptake rates could be clearly related to stomatal behavior. Despite the results obtained by the aforementioned studies, considering that $\mathrm{NO}_{2}$ resulting from traffic pollution is a primary source of pollution in urban areas, and considering that landscape plants comprise an important part of the urban ecology, studies of the effects of $\mathrm{NO}_{2}$ on plants that occupy an important position in urban green spaces should be performed. However, most previous reports have focused on field crops and herbs rather than urban landscape plants, particularly trees.

The species Carpinus betulus originates from Turkey and Ukraine (Jia, 2002). It is a deciduous broad-leaf tree in the family Betulaceae. Carpinus betulus has an attractive shape, with dense, delicate leaves in summer and golden leaves and unique fruit in autumn (Jia, 2002). Various cultivars of this species can be used for landscaping, and it has been grown in many countries. Shi et al. (2015) investigated the photosynthetic characteristics of $C$. betulus from different regions and the influence of salt stress on the photosynthetic and fluorescent characteristics of $C$. betulus seedlings. However, studies of the effects of $\mathrm{NO}_{2}$ stress on the physiological response of $C$. betulus have not been reported (Taylor and MacLean, 1970).

Based on the aforementioned results, this study aimed to address the following hypotheses: 1) $\mathrm{NO}_{2}$ treatment has a negative influence on the photosynthesis, stomatal behavior, and chloroplast ultrastructure of $C$. betulus leaves; and 2) C. betulus returns to normal growth after the removal of $\mathrm{NO}_{2}$ stress. The results of this study may provide useful reference data for the selection of plant species for atmospheric absorption and a scientific reference for plant selection for urban gardening and the construction of ecological green space landscapes.

\section{Materials and Methods}

$\mathrm{NO}_{2}$ FUMIGATION EQUIPMENT. Equipment able to control the timing
$\mathrm{NO}_{2}$ and record $\mathrm{NO}_{2}$ concentrations was used (Fig. 1). The outlet of the $\mathrm{NO}_{2}$ gas cylinders was connected to a solenoid valve with a pressure-reducing valve. A certain volume of $\mathrm{NO}_{2}$ was input into the microcomputer timer switch system. $\mathrm{An} \mathrm{NO}_{2}$ sensor was set in the fumigating chamber to detect the gas concentration. The other end of the sensor was connected to the air inlet pipe of the $\mathrm{NO}_{2}$ gasometer. The gasometer was connected to the computer terminal via an RS-485 interface. Gas-monitoring software installed in the computer was used to record the variations in $\mathrm{NO}_{2}$ concentrations of the fumigating chamber. This equipment was able to detect real-time changes in the gas in the fumigating chamber and could accurately control the volume of gas entering the chamber.

Materials. One-year-old $C$. betulus seedlings were acquired from Hungary, and the experiment was conducted in the garden plant laboratory and greenhouse of Nanjing Forestry University in Nanjing, Jiangsu Province, China (lat. $32.07^{\circ} \mathrm{N}$, long. $118.8^{\circ} \mathrm{E}$ ). In Mar. 2017, healthy seedlings (free from pests and diseases) were selected and transferred to the greenhouse for substrate cultivation. The substrate was mixed soil that contained peat, vermiculite, and pearlite at a ratio of $1: 1: 1$ by volume. The seedlings were planted in plastic pots with an upper diameter, lower diameter, and height of 30,20 , and $15 \mathrm{~cm}$, respectively. The pot had a drainage hole and was placed on a tray. In each pot, $500 \mathrm{~g}$ of dry soil was loaded, and two plants were planted. The plants grew under the same conditions $\left[25\right.$ to $28^{\circ} \mathrm{C}$, $60 \%$ to $70 \%$ air relative humidity (RH), $1500 \mu \mathrm{mol} \cdot \mathrm{m}^{-2} \cdot \mathrm{s}^{-1}$ illumination intensity] and were regularly managed. During cultivation, the plants were watered two to three times per week. One liter of Hoagland nutrient solution was applied every 2 weeks. After 2 months, the $\mathrm{NO}_{2}$ stress experiment was performed.

Fumigation AND SELf-ReCovery. Based on the literature (Liu et al., 2015; Pan et al., 2012), $\mathrm{NO}_{2}$ at $6 \mu \mathrm{L} \cdot \mathrm{L}^{-1}$ (highconcentration treatment) was used in this study. The air current velocity was set to $1 \mathrm{~L} \cdot \mathrm{min}^{-1}$, with an illumination time of $13 \mathrm{~h}$, an ambient temperature of 20 to $25^{\circ} \mathrm{C}$, and $50 \%$ to $60 \% \mathrm{RH}$. Real-time $\mathrm{NO}_{2}$ concentrations were monitored by an $\mathrm{NO}_{2}$ automatic detector. Seedlings were divided according to different fumigation periods: 0 (control), 1, 6, 12, 24, 48, and $72 \mathrm{~h}$. There were 30 pots in each treatment group.

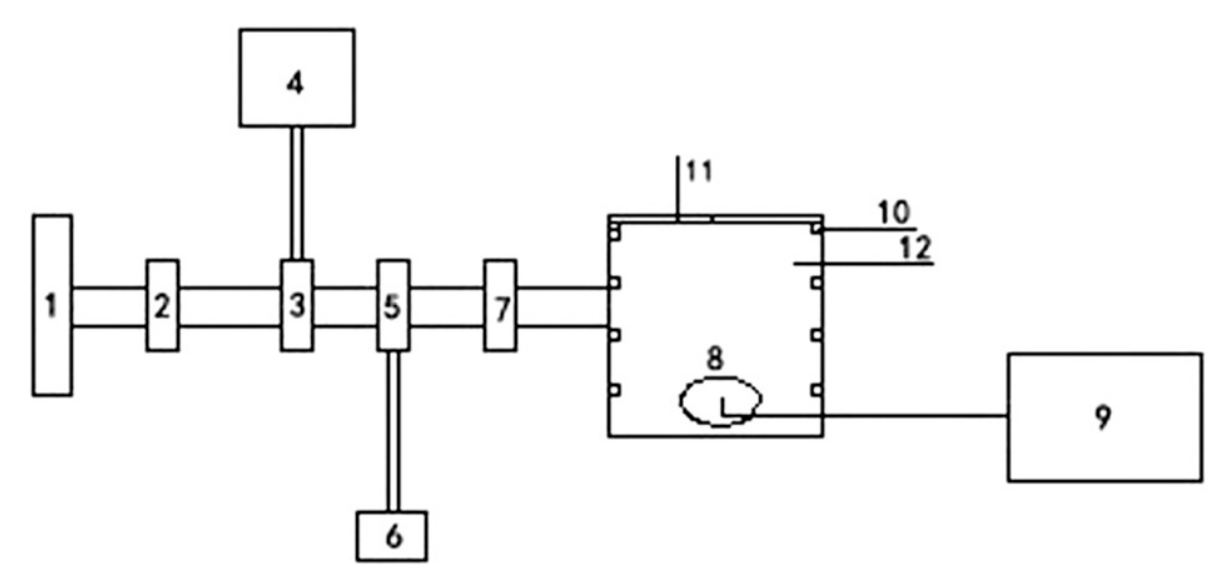

Fig. 1. A fume exhauster device with timing control and nitrogen dioxide $\left(\mathrm{NO}_{2}\right)$ concentration recording capabilities for $\mathrm{NO}_{2}$ fumigation: $1=\mathrm{NO}_{2}$ gas cylinders; $2=$ pressure-reducing valve; $3=$ solenoid valve; $4=$ microcomputer timer switch system; $5=$ centrifugal fan; $6=$ blower; $7=$ air inlet pipe; $8=\mathrm{NO}_{2}$ gas sensor; $9=$ computer terminal; $10=$ glass partition; $11=$ acrylic sheet; and $12=$ fume gas chamber. 
After the fumigation experiment, the plants were removed from the fumigation chamber and then cultivated without $\mathrm{NO}_{2}$ application in the greenhouse for $30 \mathrm{~d}$ of recovery; these plants comprised the recovery group $(n=30)$. Growth conditions were controlled to mimic environmental conditions of 25 to $28^{\circ} \mathrm{C}$, $60 \%$ to $70 \% \mathrm{RH}$, and $1500 \mu \mathrm{mol} \cdot \mathrm{m}^{-2} \cdot \mathrm{s}^{-1}$ illumination intensity by an artificial light supplement. During cultivation, the plants were regularly managed and watered two to three times per week. The water content of the soil was maintained at $60 \%$ to $80 \%$ during the experiment.

All experiments were repeated three times and performed beginning on 15 May, 15 June, and 15 July 2017. Photosynthesisrelated indices were measured immediately after treatment.

Chlorophyll CONTENT AND CARotenoid MeASuREMent. Chl content was measured spectrophotometrically (Mittler, 2002). In each treatment group, the third young leaves were taken from five plants. The midribs were removed, and the leaves were cleaned and cut into pieces. Then, they were blended. Three replicates were set for each group. The sample $(\approx 0.2 \mathrm{~g})$ was placed into a mortar, and the homogenate was made with quartz sands and calcium carbonate powder in a small quantity with $2-$ $3 \mathrm{~mL}$ of $95 \%$ ethanol. Approximately $10 \mathrm{~mL}$ of $95 \%$ ethanol was applied for further grinding until the tissue turned white. The sample was allowed to stand for 3-5 min. Then, a filter paper was placed in a funnel, and the paper was moistened with ethanol. The extraction solution was filtered into a $25-\mathrm{mL}$ brown volumetric flask. The mortar, pestle, and residues were flushed with $95 \%$ ethanol and then filtered through the funnel. The chloroplast pigment on the filter paper was washed into the flask with a dropper. The filtered solution was diluted to $25 \mathrm{~mL}$ with ethanol and shaken well. The chloroplast pigmentextracting solution was poured into a cuvette with an optical path of $1 \mathrm{~cm}$, and $95 \%$ ethanol was used as the control. Absorbance (A) was measured at wavelengths of 665, 649, and $470 \mathrm{~nm}$. The contents of $\mathrm{Chl} \mathrm{a,} \mathrm{Chl} \mathrm{b,} \mathrm{carotenoids,} \mathrm{and} \mathrm{total}$ $\mathrm{Chl}$ and the $\mathrm{Chl} \mathrm{a} / \mathrm{Chl} \mathrm{b}$ ratio were then calculated according to the method of Lichtenthaler (1987). The following equations were used: $\mathrm{Chl} \mathrm{a} \mathrm{a}_{\mathrm{c}}=13.95 \mathrm{~A}_{665}-6.88 \mathrm{~A}_{649}, \mathrm{Chl} \mathrm{b} \mathrm{b}_{\mathrm{c}}=24.96 \mathrm{~A}_{649}-$ $7.32 \mathrm{~A}_{665}$, Carotenoids $\mathrm{c}_{\mathrm{c}}=\left(1000 \mathrm{~A}_{470}-2.05 \mathrm{Chl} \mathrm{a}_{\mathrm{c}}-114.8 \mathrm{Chl} \mathrm{b}\right) /$ 245 , Total $\mathrm{Chl}_{\mathrm{m}}=\mathrm{Chl} \mathrm{a}_{\mathrm{c}}+\mathrm{Chl} \mathrm{b}_{\mathrm{c}}$, where ${ }_{\mathrm{c}}$ is the pigment concentration (milligrams per gram of extract).

Measurements of Photosynthetic parameters. The photosynthetic photon flux density $(P P F D)$ responses of the net photosynthetic rate $(\mathrm{Pn})$, intercellular carbon dioxide $\left(\mathrm{CO}_{2}\right)$ concentration $(\mathrm{Ci})$, transpiration rate $(\mathrm{Tr})$, and stomatal conductance $\left(g_{\mathrm{S}}\right)$ of $C$. betulus leaves were measured on sunny days on 15, 16, and 17 of May 2007, 15, 16, and 17 of June 2017, and 15,16 , and 17 of July 2017 (corresponding to before fumigation, after fumigation, and after $30 \mathrm{~d}$ of recovery, respectively). Between $0900 \mathrm{HR}$ and $1100 \mathrm{HR}$, nine seedlings were selected randomly from each treatment group. Three leaves below the top leaves were taken. Conjoined measurements were performed with a photosynthesis system (LI-6400XT; LI-COR, Lincoln, NE) under natural temperature, $\mathrm{RH}$, and $\mathrm{CO}_{2}$ concentration conditions $\left(25^{\circ} \mathrm{C}, 65 \%\right.$, and $350 \mu \mathrm{L} \cdot \mathrm{L}^{-1}$, respectively). Photosynthetic active radiation values at 1400, 1200, 1000, $800,600,400,200,100,50,20$, and $0 \mu \mathrm{mol} \cdot \mathrm{m}^{-2} \cdot \mathrm{s}^{-1}$ were used for photosynthesis rate measurements. Data at each light intensity value were collected for $5 \mathrm{~min}$.

Measurement of diURNAL VARIATION IN PHOtosynthesis. Between $0800 \mathrm{HR}$ and $1800 \mathrm{HR}$, nine seedlings were selected randomly from each treatment group. Three leaves below the top leaves were taken. Conjoined measurements were performed with a photosynthesis system (LI-6400XT) under natural conditions $\left(25{ }^{\circ} \mathrm{C}, 65 \% \mathrm{RH}, 350 \mu \mathrm{L} \cdot \mathrm{L}^{-1} \mathrm{CO}_{2}\right.$, and natural light). Three groups of data were recorded for each leaf, and measurements were performed once every $2 \mathrm{~h}$. Measurements were performed for three consecutive days, and the averages were obtained. The indices, including $\mathrm{Pn}, \mathrm{Ci}$, and $g_{\mathrm{S}}$, were measured repeatedly for all fumigation times, which were $0,1,6,12,24,48$, and $72 \mathrm{~h}$ and self-recovery.

SCANNING EleCtron microscopy. After $\mathrm{NO}_{2}$ stress, leaf samples were taken from different treatment groups. The leaves were sectioned transversely with a double-edged blade. Samples were fixed with $4 \%$ glutaral for $6 \mathrm{~h}$ and then washed with $0.1 \mathrm{M}$ phosphate buffer (10 min for each washing). Then, 2\% osmic acid was used for fixation until the sample turned black and transparent. The sample was washed with $0.1 \mathrm{M}$ phosphate buffer (10 min for each washing). Dehydration was performed with $30 \%$ ethanol for $15 \mathrm{~min}, 50 \%$ ethanol for $15 \mathrm{~min}, 70 \%$ ethanol for $15 \mathrm{~min}$, and $90 \%$ ethanol for $15 \mathrm{~min}$. Finally, dehydration was performed twice with $100 \%$ ethanol for $15 \mathrm{~min}$ each. The sample was placed in a drying basket and dried with a critical point dryer. The dried sample was stuck to the sample table with electric conduction paste and then subjected to metal spraying (15 $\mathrm{mA}$ for $2 \mathrm{~min}$ ). A scanning electron microscope (TM4000/TM4000Plus; Hitachi High-Technologies, Tokyo, Japan) was used for observation.

Transmission Electron Microscopy. Fresh samples were rapidly cut into 1 - to $3-\mathrm{mm}^{2}$ pieces and then fixed in $4 \%$ glutaral. After complete precipitation $(\approx 4 \mathrm{~h}$ later $)$, the samples were washed three times with phosphate buffer $(20 \mathrm{~min}$ for each washing). Then, the samples were fixed with $2 \%$ osmic acid until they turned black and transparent. The samples were washed with phosphate buffer three times $(20 \mathrm{~min}$ for each washing). Gradient dehydration was performed with $30 \%$, $50 \%, 70 \%$, and $90 \%$ acetone (30 min for each gradient). Then, dehydration with $100 \%$ acetone was performed twice $(30 \mathrm{~min}$ each). The samples were embedded and then incubated at 37 , 45 , and $60{ }^{\circ} \mathrm{C}$ overnight for polymerization.

Ultrathin sections were made with an ultramicrotome (LKB-V; LKB, Bromma, Switzerland) and had a thickness of 50-70 nm. Uranium-lead staining was performed. A transmission electron microscope (JEM-1400 Plus; Hitachi High-Technologies) was used for observation.

STATISTICAL ANALYSIS. Data are presented as the mean \pm standard deviation and were processed using SPSS software (version 24.0; IBM, Armonk, NY). The nonparametric Kruskal-Wallis onefactor analysis of variance was used for comparisons between and among groups. The level of significance was adjusted using the Bonferroni method. An adjusted $P<0.05\left(\alpha^{\prime}\right)$ was considered significant.

\section{Results}

Chlorophyll Concentrations. Different $\mathrm{NO}_{2}$ treatment groups exhibited noticeable differences in $\mathrm{Chl}$ concentration (Table 1). The concentrations of $\mathrm{Chl}$ a, carotenoids, and total $\mathrm{Chl}$ and the $\mathrm{Chl} \mathrm{a/Chl} \mathrm{b}$ ratio noticeably decreased with the prolongation of $\mathrm{NO}_{2}$ fumigation. Compared with the control group $(0 \mathrm{~h})$, the $72-\mathrm{h} \mathrm{NO}_{2}$ treatment group showed significant differences in the $\mathrm{Chl} \mathrm{a} / \mathrm{Chl} \mathrm{b}$ ratio and the carotenoid concentration (both adjusted $P=0.008$ ). In contrast, all indices of the recovery group ( $30 \mathrm{~d}$ after recovery) increased compared 
with those of the $\mathrm{NO}_{2}$ treatment groups and exhibited significant differences in the $\mathrm{Chl} \mathrm{a}, \mathrm{Chl} \mathrm{b}$, and total Chl concentrations compared with those of the 72-h treatment group (all adjusted $P=0.008$ ). No significant differences in the concentrations of $\mathrm{Chl}$ a, carotenoids, and total $\mathrm{Chl}$ or the $\mathrm{Chl} \mathrm{a/} \mathrm{Chl} \mathrm{b}$ ratio were observed between the control group and the recovery group.

Photosynthetic Indices. Diurnal variations in Pn were bimodal. The Pn peak values were highest at $1200 \mathrm{HR}$ and $1600 \mathrm{HR}$, and the "midday rest" phenomenon appeared at 1400 HR among the recovery, control, and $\mathrm{NO}_{2}$ treatments (Fig. 2A). The Pn peak value showed a decreasing trend with increasing $\mathrm{NO}_{2}$ treatment concentrations, but it was lower than the control and recovery values (detailed pairwise comparisons among groups at different diurnal time points are shown in Supplemental Fig. 1).

The $\mathrm{Tr}$ values for all $\mathrm{NO}_{2}$ treatment groups except for the 1-h group increased and then decreased, with the maximum value obtained at $1200 \mathrm{HR}$. The Tr values of the treatment groups were lower than those of the control group and recovery group (Fig. 2B); however, no significant difference was observed between the control group and recovery group (Supplemental Fig. 2).

The $g_{\mathrm{S}}$ values of the 6-, 24-, 48-, and 72-h treatment groups increased and then decreased, with the maximum value obtained at $1000 \mathrm{HR}$ (Fig. 2C). All treatment groups except for the 6-h treatment group showed a noticeable difference compared with the control group and recovery group. Compared

Table 1. Leaf chlorophyll (Chl) a concentrations, $\mathrm{Chl} \mathrm{b}$ concentrations, Chl a/Chl b ratios, carotenoid concentrations, and total chlorophyll concentrations after exposure of european hornbeam leaves to $6 \mu \mathrm{L} \cdot \mathrm{L}^{-1}$ of $\mathrm{NO}_{2}$ for $0,1,6,12,24,48$, and $72 \mathrm{~h}$ and after self-recovery $(\mathrm{n}=3$ ).

\begin{tabular}{lcccc}
\hline & \multicolumn{3}{c}{ Mean \pm SD } \\
\cline { 2 - 5 } Group & $\begin{array}{c}\text { Chl a concn } \\
\left(\mathrm{mg} \cdot \mathrm{g}^{-1} \mathrm{FW}\right)\end{array}$ & $\begin{array}{c}\text { Chl b concn } \\
\left(\mathrm{mg} \cdot \mathrm{g}^{-1} \mathrm{FW}\right)\end{array}$ & $\begin{array}{c}\text { Chl a/Chl b }(\mathrm{ratio}) \\
\text { Carotenoid concn } \\
\left(\mathrm{mg} \cdot \mathrm{g}^{-1} \mathrm{FW}\right)\end{array}$ & $\begin{array}{c}\text { Total Chl concn } \\
\left(\mathrm{mg} \cdot \mathrm{g}^{-1} \mathrm{FW}\right)\end{array}$ \\
\hline Control & $15.13 \pm 0.56$ & $4.84 \pm 0.15$ & $3.12 \pm 0.15 \mathrm{~A}^{\mathrm{z}}$ & $2.81 \pm 0.01 \mathrm{~A}$ \\
$1 \mathrm{~h}$ & $10.47 \pm 0.15$ & $5.10 \pm 0.10$ & $2.13 \pm 0.06$ & $2.05 \pm 0.04$ \\
$6 \mathrm{~h}$ & $9.24 \pm 0.05$ & $4.26 \pm 0.51$ & $2.15 \pm 0.01$ & $1.72 \pm 0.01$ \\
$12 \mathrm{~h}$ & $9.02 \pm 0.01$ & $4.07 \pm 0.50$ & $2.25 \pm 0.01$ & $1.61 \pm 0.01$ \\
$24 \mathrm{~h}$ & $8.88 \pm 0.01$ & $3.72 \pm 0.25$ & $2.05 \pm 0.05$ & $1.02 \pm 0.02$ \\
$48 \mathrm{~h}$ & $8.87 \pm 0.06$ & $3.65 \pm 0.15$ & $1.87 \pm 0.05$ & $0.72 \pm 0.01$ \\
$72 \mathrm{~h}$ & $8.56 \pm 0.01$ & $3.31 \pm 0.15$ & $1.62 \pm 0.01$ & 2.01 \\
Recovery & $16.14 \pm 0.05 \mathrm{~A}$ & $7.16 \pm 0.15 \mathrm{~A}$ & $2.25 \pm 0.15$ & $13.01 \pm 0.01$ \\
\end{tabular}

${ }_{\mathrm{z}}$ Data analysis was performed in the same column using Kruskal-Wallis one-factor analysis of variance, and A indicates adjusted $P=0.008$ vs. the 72-h group in the same column, after Bonferroni correction.

$\mathrm{FW}=$ fresh weight.
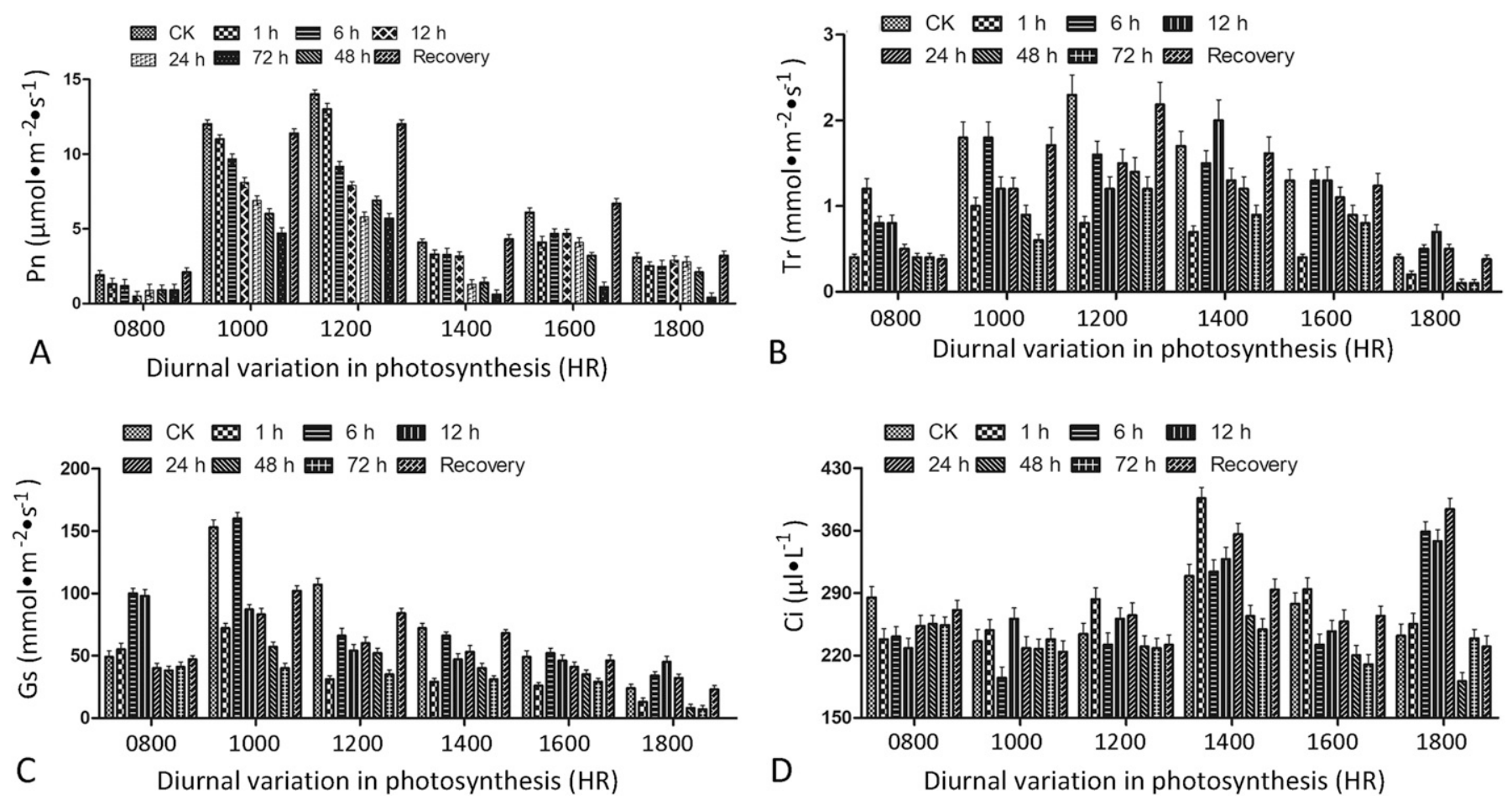

Fig. 2. Diurnal change in photosynthesis $\left[(\mathbf{A})\right.$ net photosynthetic rate $(\mathrm{Pn}),(\mathbf{B})$ transpiration rate $(\mathrm{Tr}),(\mathbf{C})$ stomatal conductance $\left(g_{\mathrm{S}}\right)$, and $(\mathbf{D})$ intercellular $\mathrm{CO}_{2}$ concentration (Ci)] in leaves of european hornbeam grown under exposure to $6 \mu \mathrm{L} \cdot \mathrm{L}^{-1}$ of $\mathrm{NO}_{2}$ for 0 [control $\left.(\mathrm{CK})\right], 1,6,12,24,48$, and $72 \mathrm{~h}$ and after $30 \mathrm{~d}$ of selfrecovery. 

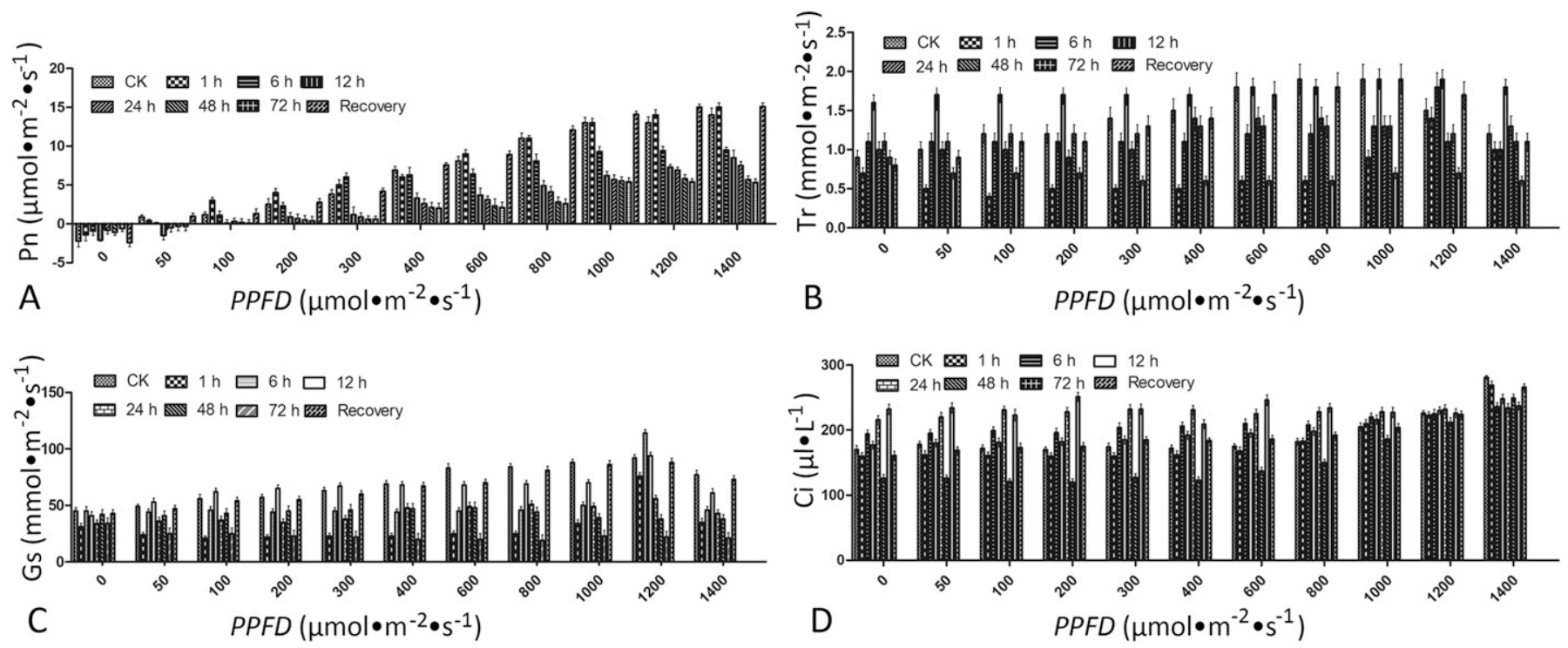

Fig. 3. Photosynthesis irradiance $(P A R)$ responses [(A) net photosynthetic rate $(\mathrm{Pn}),(\mathbf{B})$ transpiration rate $(\mathrm{Tr}),(\mathbf{C})$ stomatal conductance $\left(g_{\mathrm{S}}\right)$, and $(\mathbf{D})$ intercellular $\mathrm{CO}_{2}$ concentration $\left.(\mathrm{Ci})\right]$ in leaves of european hornbeam grown under exposure to $6 \mu \mathrm{L} \cdot \mathrm{L}^{-1}$ of $\mathrm{NO}_{2}$ for 0 [control $(\mathrm{CK})$ ], 1, 6, 12, 24, 48, and 72 h and after $30 \mathrm{~d}$ of self-recovery; $P P F D=$ photosynthetic photon flux density.
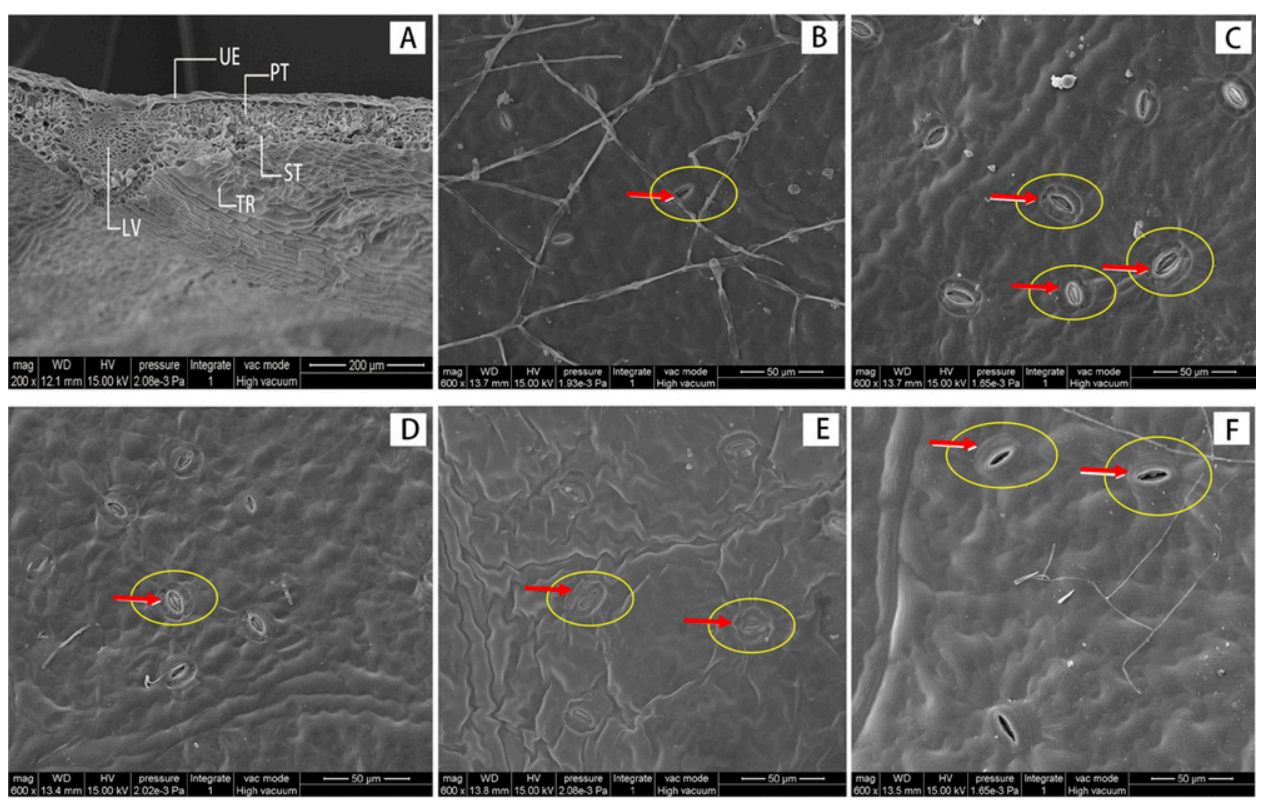

Fig. 4. Scanning electron microscope (SEM) images of the stomata of european hornbeam leaves of the control group [CK $(0 \mathrm{~h})$ ] exposed to $6 \mu \mathrm{L} \cdot \mathrm{L}^{-1}$ of $\mathrm{NO}_{2}$ for 1,24 , and $72 \mathrm{~h}$ and after $30 \mathrm{~d}$ of self-recovery based on two scale bars $(50$ and $200 \mu \mathrm{m})$. (A) Microstructure of leaves without $\mathrm{NO}_{2}$ treatment. (B) Normal stomatal state of the leaves without $\mathrm{NO}_{2}$ treatment. (C-E) Increased number of closed stomata on abaxial surfaces with the increased timing of $\mathrm{NO}_{2}$ treatment in comparison with the controls and self-recovered plants. (F) Stomatal state of the leaves after $30 \mathrm{~d}$ of recovery. $\mathrm{UE}=$ upper epidermis, $\mathrm{PT}=$ palisade tissue, $\mathrm{ST}=$ spongy tissue, $\mathrm{LV}=$ leaf vein, $\mathrm{TR}=$ trichomes.

with the other treatment groups, the 72-h group had the lowest $g_{\mathrm{S}}$ value (Supplemental Fig. 3). For all $\mathrm{NO}_{2}$ treatment groups, the $\mathrm{Ci}$ value did not exhibit a significant difference between $0800 \mathrm{HR}$ and 1400 HR (Fig. 2D; Supplemental Fig. 4); after 1400 HR, the Ci value decreased.

The bar charts of $\mathrm{Pn}, \mathrm{Tr}, g_{\mathrm{S}}$, and $\mathrm{Ci}$ under eight light intensities based on the PPFD responses are shown in Fig. 3 . With the increased light intensity from 0 to $1400 \mu \mathrm{mol} \cdot \mathrm{m}^{-2} \cdot \mathrm{s}^{-1}$, the Pn value of all $\mathrm{NO}_{2}$ treatment groups increased rapidly. When the light intensity reached 1400 $\mu \mathrm{mol} \cdot \mathrm{m}^{-2} \cdot \mathrm{s}^{-1}$, the Pn values of the 48- and 72-h treatment groups increased gradually to the maximum value and became stable. At a light intensity of $1400 \mu \mathrm{mol} \cdot \mathrm{m}^{-2} \cdot \mathrm{s}^{-1}$, the Pn value of the 6-h treatment group increased rapidly to the maximum value of $15 \mu \mathrm{mol} \cdot \mathrm{m}^{-2} \cdot \mathrm{s}^{-1}$. The values of the control and recovery groups increased slowly to the maximum values, which were 14 and 15.1 $\mu \mathrm{mol} \cdot \mathrm{m}^{-2} \cdot \mathrm{s}^{-1}$, respectively (Fig. 3A).

The $\operatorname{Tr}$ value varied with the $\mathrm{NO}_{2}$ treatment time (Fig. 3B). With the increase in light intensity, the $\operatorname{Tr}$ values of the 1-h and 6-h treatment groups increased steadily and peaked at 1200 $\mu \mathrm{mol} \cdot \mathrm{m}^{-2} \cdot \mathrm{s}^{-1}$. The Tr value of the $12-\mathrm{h}$ $\mathrm{NO}_{2}$ treatment group was higher than that of any other $\mathrm{NO}_{2}$ treatment group, and no noticeable $\operatorname{Tr}$ variations were observed for the 24-, 48-, and 72-h $\mathrm{NO}_{2}$ treatment groups.

The $g_{\mathrm{S}}$ values for all $\mathrm{NO}_{2}$ treatment groups except for the 48- and 72-h groups increased and then decreased, and they peaked when the light intensity was 1200 $\mu \mathrm{mol} \cdot \mathrm{m}^{-2} \cdot \mathrm{s}^{-1}$ (Fig. $3 \mathrm{C}$ ). Among all $\mathrm{NO}_{2}$ treatment groups, the 6-h group had the highest $g_{\mathrm{S}}$ value. With the increased light intensity, the 48- and 72-h treatment groups did not exhibit noticeable changes in the $g_{\mathrm{S}}$ value.

The $\mathrm{Ci}$ value of all $\mathrm{NO}_{2}$ treatment groups decreased and then increased, except for that of the 72-h treatment group, which did not show any noticeable change (Fig. 3D). At a light intensity of 

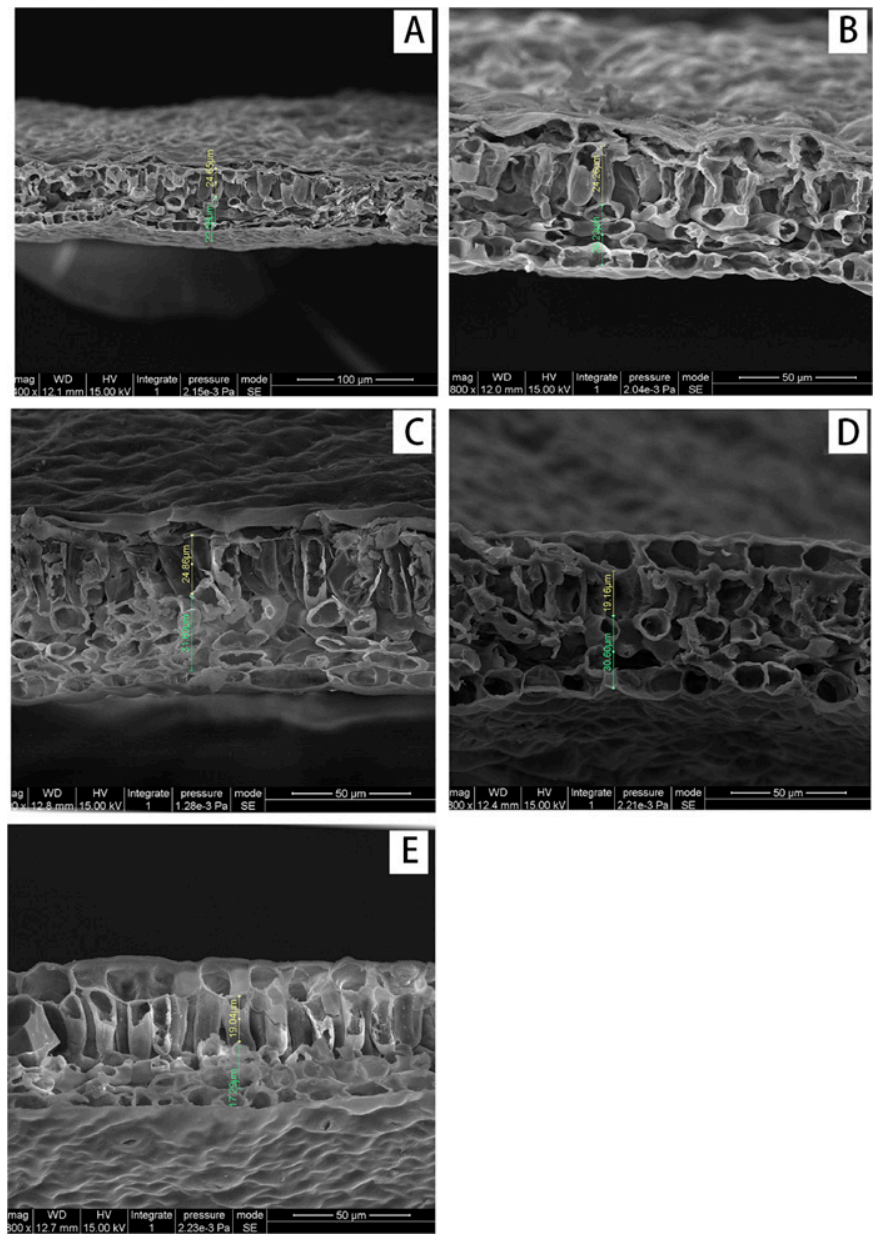

Fig. 5. Scanning electron microscope (SEM) images of palisade tissue and spongy tissue of the european hornbeam leaves of the control group [CK $(0 \mathrm{~h})]$ exposed to $6 \mu \mathrm{L} \cdot \mathrm{L}^{-1}$ of $\mathrm{NO}_{2}$ for 1,24 , and $72 \mathrm{~h}$ and after $30 \mathrm{~d}$ of self-recovery based on two scale bars $(50$ and $100 \mu \mathrm{m})$. (A) Normal palisade tissue and spongy tissue in the leaves without $\mathrm{NO}_{2}$ treatment. (B-D) Thicknesses of the palisade and spongy tissues increased after $\mathrm{NO}_{2}$ treatment compared with those of the controls and self-recovered plants. (E) Palisade tissue and spongy tissue of the leaves after $30 \mathrm{~d}$ of recovery.

$50 \mu \mathrm{mol} \cdot \mathrm{m}^{-2} \cdot \mathrm{s}^{-1}$, the $\mathrm{Ci}$ values of the 6-, 12-, and 24-h $\mathrm{NO}_{2}$ treatment groups displayed the minimum value.

Anatomical and Stomatal Leaf STRuctures. The stomatal sizes of the control, 1-, 24-, 72-h, and recovery groups are shown in Fig. 4B-4F. Wrinkles were observed in the guard cells around the stomata of the 1-, 24-, and 72-h treatment groups. Scanning electron microscopy showed that the stomata of $C$. betulus were on both surfaces. The opening size of the stomata decreased with the prolongation of $\mathrm{NO}_{2}$ treatment, and the stomata closed after $72 \mathrm{~h}$ of $\mathrm{NO}_{2}$ treatment. After $30 \mathrm{~d}$ of recovery, the stomata opened again and returned to the normal aperture level.

The thicknesses of the spongy and palisade tissues of the 1-, $24-$, and $72-\mathrm{h} \mathrm{NO}_{2}$ treatment groups were $106.9 \%, 112 \%$, and $87.9 \%$ of those of the control group, respectively (Fig. 5A-E). In contrast, the thicknesses of the spongy and palisade tissues of the recovery group were $73 \%$ of those of the control group $(P<$ 0.05 ), indicating that recovery had a positive effect on the leaf structure of $C$. betulus.

ULTRASTRUCTURE OF CHLOROPLASTS. In the control group, the chloroplasts had an oval shape and contained a large number of
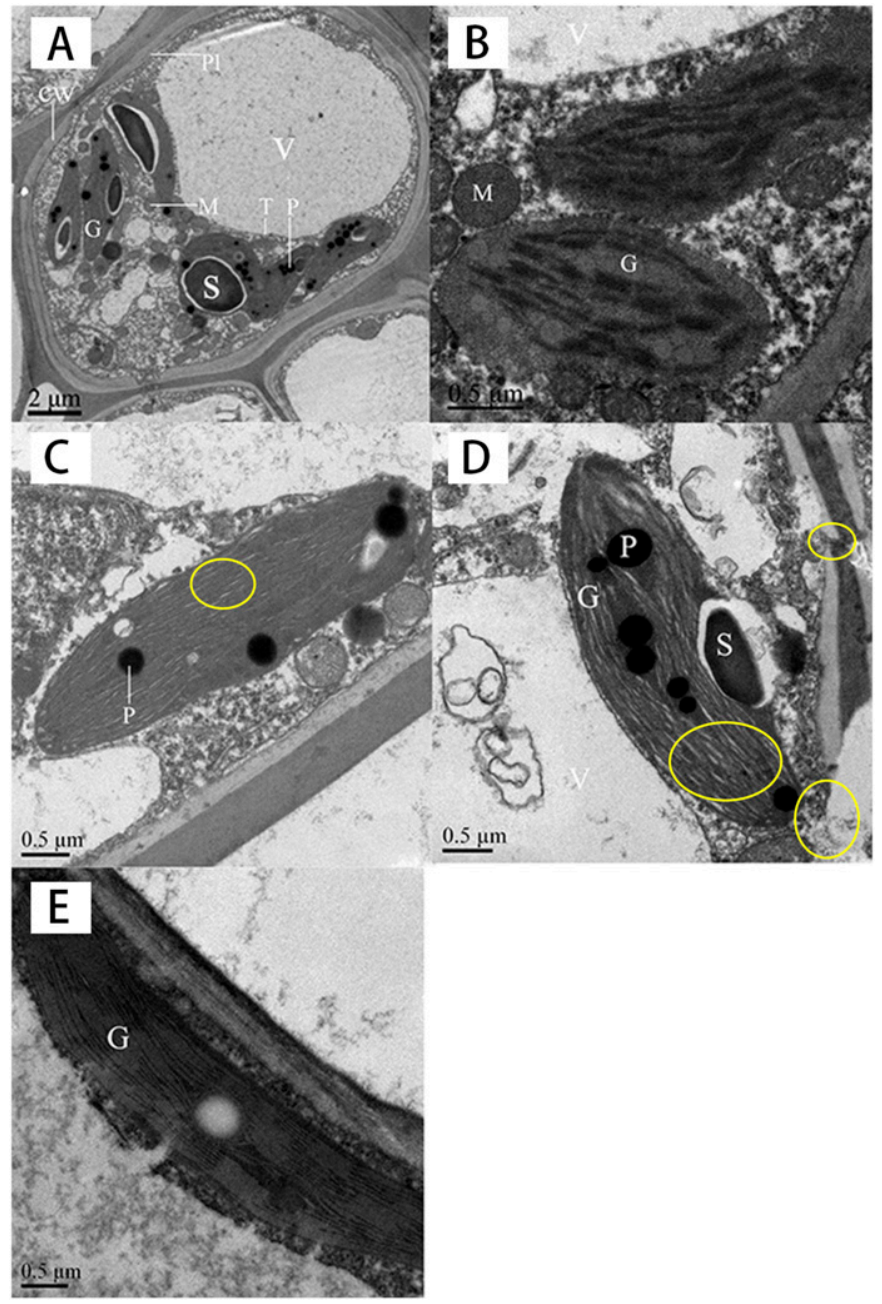

Fig. 6. Transmission electron microscope (TEM) micrographs of chloroplasts from european hornbeam leaves of the control group [CK $(0 \mathrm{~h})$ ], $6 \mu \mathrm{L} \cdot \mathrm{L}^{-1} \mathrm{NO}_{2}$-treated $(1,24$, and $72 \mathrm{~h}$, respectively) and self-recovery plants. (A) CK plant with a discoidal chloroplast containing abundant wellcompartmentalized grana. (B) Chloroplast with complete leaf structures in the 1-h treatment group. (C) Slightly changed chloroplasts with dilated thylakoid (yellow oval) in the 24-h treatment group. (D) Extensively damaged chloroplasts in the 72-h treatment group showing grossly dilated thylakoids (yellow oval). (E) Chloroplasts with complete leaf structures after $30 \mathrm{~d}$ of self-recovery. $\mathrm{C}=$ cytoplasm, $\mathrm{M}=$ mitochondria, $\mathrm{P}=$ plastoglobuli, $\mathrm{Pl}=$ primary leaf, $\mathrm{S}=$ starch grain, $\mathrm{T}=$ tonoplast, $\mathrm{V}=$ vacuole, $\mathrm{CW}=$ cell wall, $\mathrm{G}=$ grana stack .

basic granules and thylakoids (Fig. 6A). $\mathrm{NO}_{2}$ treatment had a remarkable effect on the shape of chloroplasts. In the 1-h treatment group, the chloroplasts showed a normal ultrastructure in the basic granule arrangement and thylakoid morphology (Fig. 6B). In the 24-h treatment group, fewer than $10 \%$ of the chloroplasts presented with slight damage, such as slight loosening and swelling of the thylakoids (yellow oval in Fig. $6 \mathrm{C})$. In the $72-\mathrm{h}$ treatment group, a large number of chloroplasts presented with severely swelling thylakoids (yellow oval in Fig. 6D). Compared with the 24- and 72-h treatment groups, the 1-h group possessed many more thylakoids. In the recovery group, the chloroplasts showed a disc-like shape (Fig. 6E), most chloroplasts returned to their normal shape, and the negative effects of $\mathrm{NO}_{2}$ stress on the functions of thylakoids nearly disappeared. 


\section{Discussion}

In this study, we explored the effects of $\mathrm{NO}_{2}$ treatment according to different exposure times on the photosynthesis, stomatal behavior, and chloroplast ultrastructure of $C$. betulus leaves. Then, we observed the recovery state of $C$. betulus under simulated natural growth conditions. Our results showed that although the severity of the effects of $\mathrm{NO}_{2}$ treatment on the Chl content in $C$. betulus leaves varied according to exposure time, $\mathrm{NO}_{2}$ stress generally caused a decrease in Chl content in the leaves. These results were consistent with the conclusions of Liu et al. (2015), who reported that $\mathrm{NO}_{2}$ stress at different concentrations $\left(3.48,8.2,17.4\right.$, and $\left.38.5 \mu \mathrm{L} \cdot \mathrm{L}^{-1}\right)$ decreased the chloroplast content in the mesophyll tissue of $A$. thaliana shoots. Nitrogen is an indispensable element for $\mathrm{Chl}$ synthesis (Croft et al., 2017). We speculated that after $\mathrm{NO}_{2}$ treatment, $\mathrm{NO}_{2}$ around the leaves combined with moisture to form nitric acids or nitrous acids, which had an acidification effect on mesophyll cells. This process further affected the antioxidant defense system of the organism and inhibited the synthesis of Chl, resulting in difficulty in the absorption of nutrient elements (such as nitrogen and phosphorus) of the plant. Furthermore, $\mathrm{NO}_{2}$ stress increased the activity of chlorophyllase, which expedited the decomposition of $\mathrm{Chl}$ and decreased the light energy absorption of chloroplasts.

In this study, we used scanning electron microscopy and transmission electron microscopy to analyze the changes in stomatal behavior, the thicknesses of palisade and spongy tissues, and the chloroplast structure of $C$. betulus leaves after $\mathrm{NO}_{2}$ treatment. It has been assumed that the factors related to the decrease in Pn under adversity include stomatal factors and nonstomatal factors (Cai et al., 2013). Under $\mathrm{NO}_{2}$ stress, both stomatal and nonstomatal factors exist; atmospheric $\mathrm{NO}_{2}$ deposits on the surface of the leaves and enters the mesophyll cells via the stoma. Photosynthesis capability is an important index for judging the adaptability of plants to certain environments (Cai et al., 2013). Additionally, the response to extreme environments is another index for judging the adaptability of plants. This study showed that $6 \mu \mathrm{L} \cdot \mathrm{L}^{-1}$ of $\mathrm{NO}_{2}$ had an inhibitory effect on the Pn, $g_{\mathrm{S}}$, and $\operatorname{Tr}$ values of $C$. betulus leaves (Fig. 2), which indicated that $C$. betulus performs a series of regulatory behaviors to decrease photosynthesis after long-term $\mathrm{NO}_{2}$ exposure, such as closing the stoma to reduce $\mathrm{NO}_{2}$ acidification.

To ensure normal photosynthesis within C. betulus leaves, the chloroplasts in the mesophyll cells must have a complete and normal configuration and structure, such as an integral outer shell with a clear boundary and developed thylakoids. In this study, the 24- and 72-h $\mathrm{NO}_{2}$ treatment groups exhibited fewer thylakoids among the basic granules inside the leaves than did the 1-h $\mathrm{NO}_{2}$ treatment group. In contrast, the control group and recovery group showed a better configuration of chloroplasts and basic granules, lower $\mathrm{Pn}$, and lower pigment content than the $1-\mathrm{h} \mathrm{NO} \mathrm{NO}_{2}$ treatment group. According to the literature (Rantanen et al., 1994; Schiffgens-Gruber and Lutz, 1992), sulfur dioxide $\left(\mathrm{SO}_{2}\right)$ and $\mathrm{NO}_{2}$ decrease the number of basic granules and cause thylakoids to swell. Our results are consistent with those reported in the literature. Presumably, the 1-h $\mathrm{NO}_{2}$ treatment may have had a promotive effect on plant growth because the development of chloroplasts resorted to regulating the number of thylakoids and the grana lamella, whereas $\mathrm{NO}_{2}$ treatment for more than $24 \mathrm{~h}$ harmed the physiological growth of the plants.
To date, among the studies of damage remission of plants after $\mathrm{NO}_{2}$ exposure, most adopted foreign matters, such as hydrogen peroxide $\left(\mathrm{H}_{2} \mathrm{O}_{2}\right)(\mathrm{Wu}$ et al., 1995) and ascorbic acid (Shalata and Neumann, 2001). Studies of metabolism repair via autoregulation, without the addition of foreign matter, have not been reported. In this study, we found that natural repair of C. betulus benefited the thicknesses of palisade and spongy tissues, chloroplast content, and $\mathrm{Pn}$ in the leaves of $\mathrm{NO}_{2}$-treated C. betulus. These results may provide new ideas for functional gardening and the construction of ecological green space landscapes.

In conclusion, $6 \mu \mathrm{L} \cdot \mathrm{L}^{-1}$ of $\mathrm{NO}_{2}$ damages the ultrastructure of the chloroplasts in $C$. betulus leaves. This condition has a direct negative effect on the $\mathrm{Chl}$ content and photosynthesis of the leaves. The reason for the decrease in the $\mathrm{Chl}$ content is that absorption of a large volume of $\mathrm{NO}_{2}$ within a short time by mesophyll cells causes cellular acidification, which damages the cellular membrane and changes cell permeability, resulting in chloroplast damage. However, a certain period of natural recovery can strengthen the ultrastructure or biosynthesis of chloroplasts, enhance photosynthesis, and improve the stomatal aperture, thus increasing the physiological metabolism of $C$. betulus.

\section{Literature Cited}

Bermejo-Orduna, R., J.R. McBride, K. Shiraishi, D. Elustondo, E. Lasheras, and J.M. Santamaría. 2014. Biomonitoring of trafficrelated nitrogen pollution using Letharia vulpina (L.) Hue in the Sierra Nevada, California. Sci. Total Environ. 490:205-212.

Cai, S.Z., X. Li, Y.Z. Pan, J. Li, T.X. Hu, and C. Ye. 2013. A study on photosynthetic characteristics and growth and development of Iris japonica under different illumination. Caoye Xuebao 22:264-272.

Chai, Y.X., N. Zhu, and H.J. Han. 2002. Hysteresis effect of dust on urban greening tree species in Harbin city. J. Appl. Ecol. 13:11211126.

Chaparro-Suarez, I.G., F.X. Meixner, and J. Kesselmeier. 2011. Nitrogen dioxide $\left(\mathrm{NO}_{2}\right)$ uptake by vegetation controlled by atmospheric concentrations and plant stomatal aperture. Atmos. Environ. 45:5742-5750.

Chen, Z.M., Y.X. Chen, G.J. Du, X.L. Wu, and F. Li. 2010. Effects of 60-day $\mathrm{NO}_{2}$ fumigation on growth, oxidative stress and antioxidative response in Cinnamomum camphora seedlings. J. Zhejiang Univ. Sci. B 11:190-199.

Croft, H., J.M. Chen, X.Z. Luo, P. Bartlett, B. Chen, and R.M. Staebler. 2017. Leaf chlorophyll content as a proxy for leaf photosynthetic capacity. Glob. Change Biol. 23:3513-3524.

Fink, S. 1988. Histological and cytological changes caused by air pollutants and other abiotic factors, p. 36-54. In: N.M. Darrall, L.W. Blank, and A.R. Wellburn (eds.). Air pollution and plant metabolism. Elsevier Appl. Sci., Barking, UK.

Frati, L., G. Brunialti, and S. Loppi. 2008. Effects of reduced nitrogen compounds on epiphytic lichen communities in Mediterranean Italy. Sci. Total Environ. 407:630-637.

Furukawa, A., M. Yokoyama, T. Ushijima, and T. Totsuka. 1984. The effects of $\mathrm{NO}_{2}$ and/or $\mathrm{O}_{3}$ on photosynthesis of sunflower leaves. Res. Rpt. Natl. Inst. Environ. Studies Jpn. 65:89-97.

Hu, Y.B., N. Bellaloui, M. Tigabu, J.H. Wang, J. Diao, K. Wang, R. Yang, and G.Y. Sun. 2015. Gaseous $\mathrm{NO}_{2}$ effects on stomatal behavior, photosynthesis and respiration of hybrid poplar leaves. Acta Physiol. Plant. 37:39.

Huttunen, S. and S. Soikkeli. 1984. Effects of various gaseous pollutants on plant cell ultrastructure, p. 117-127. In: M.J. Koziol and F.R. Whatley (eds.). Gaseous air pollutants and plant metabolism. Butterworths, London, UK.

Jia, Y. 2002. Rambling Carpinus. Bonsai Flowers Trees 10:62. 
Lichtenthaler, H.K. 1987. Chlorophylls and carotenoids: Pigments of photosynthetic biomembranes. Methods Enzymol. 148:350-382.

Liu, X.F., F. Hou, G.K. Li, and N. Sang. 2015. Effects of nitrogen dioxide and its acid mist on reactive oxygen species production and antioxidant enzyme activity in Arabidopsis. J. Environ. Sci. (China) 34:93-99.

Lu, M., Y.J. Li, and J.P. Lu. 2002. The study of greening trees on the atmospheric pollutant absorption ability. Urban Environ. Urban Ecol. 15:7-9.

Mittler, R. 2002. Oxidative stress, antioxidants and stress tolerance. Trends Plant Sci. 7:405-410.

Munzi, S., T. Pisani, and S. Loppi. 2009. The integrity of lichen cell membrane as a suitable parameter for monitoring biological effects of acute nitrogen pollution. Ecotoxicol. Environ. Saf. 72:2009-2012. Nanjing Environmental Protection Bureau. 2016. Environment quality bulletin. 6 Apr. 2018. <http://www.njhb.gov.cn/43462/43464/ 201606/P020160604379598118347.pdf>.

Rahmat, M., W. Maulina, E. Rustami, M. Azis, D.R. Budiarti, K.B. Seminar, A.S. Yuwono, and H. Alatas. 2013. Performance in real condition of photonic crystal sensor based $\mathrm{NO}_{2}$ gas monitoring system. Atmos. Environ. 79:480-485.

Pan, W., W.Q. Zhang, and F.Q. Zhang. 2012. The resistance of $\mathrm{SO}_{2}$ and $\mathrm{NO}_{2}$ to Rhodoleia championii. J. Ecol. Environ. 21:1851-1858.

Rantanen, L., V. Palomakp, A.F. Harrison, P.W. Lucas, and T.A. Mansfield. 1994. Interactions between combined exposure to $\mathrm{SO}_{2}$ and $\mathrm{NO}_{2}$ and nutrient status of trees: Effects on nutrient content and uptake, growth, needle ultrastructure and pigments. New Phytol. 128:689-701.
Schiffgens-Gruber, A. and C. Lütz. 1992. Ultrastructure of mesophyll cell chloroplasts of spruce needles exposed to $\mathrm{O}_{3}, \mathrm{SO}_{2}$ and $\mathrm{NO}_{2}$ alone and in combination. Environ. Expt. Bot. 32:243-254.

Shalata, A. and P.M. Neumann. 2001. Exogenous ascorbic acid (vitamin C) increases resistance to salt stress and reduces lipid peroxidation. J. Expt. Bot. 52:2207-2211.

Shi, M., L.X. Cheng, and Z.L. Zhu. 2015. The photosynthesis characteristic research in different areas. J. Southwest Agr. 28: 105-109.

Taylor, O.C. and D.C. MacLean. 1970. Nitrogen oxides and the peroxyacyl nitrates, p. E1-E14. In: J.S. Jacobson and A.C. Hill (eds.). Recognition of air pollution injury to vegetation: A pictorial atlas. Air Pollution Control Assn., Pittsburgh, PA.

van der A, R.J., H.J. Eskes, K.F. Boersma, T.P.C. van Noije, M. Van Roozendael, and I. de Smedt. 2008. Trends, seasonal variability and dominant NOx source derived from a ten-year record of $\mathrm{NO}_{2}$ measured from space. J. Geophys. Res. 113:D04302.

Wellburn, A.R. 1990. Why are atmospheric oxides of nitrogen usually phytotoxic and not alternative fertilizers? New Phytol. 115:395-429. Wellburn, A.R., O. Majernik, and F.A.M. Wellburn. 1972. Effects of $\mathrm{SO}_{2}$ and $\mathrm{NO}_{2}$ polluted air upon the ultrastructure of chloroplasts. Environ. Pollut. 3:37-49.

Wu, G., B.J. Shortt, E.B. Lawrence, E.B. Levine, K.C. Fitzsimmons, and D.M. Shah. 1995. Disease resistance conferred by expression of a gene encoding $\mathrm{H}_{2} \mathrm{O}_{2}$-generating glucose oxidase in transgenic potato plants. Plant Cell 7:1357-1368. 


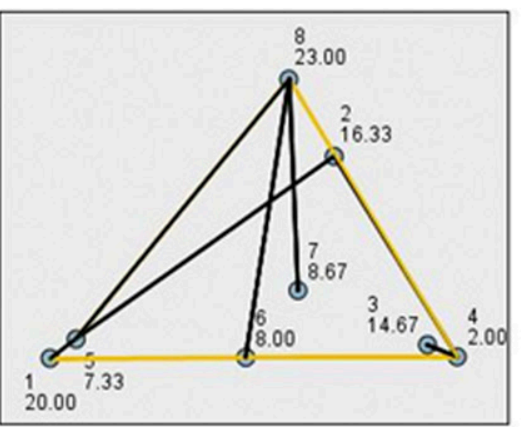

A

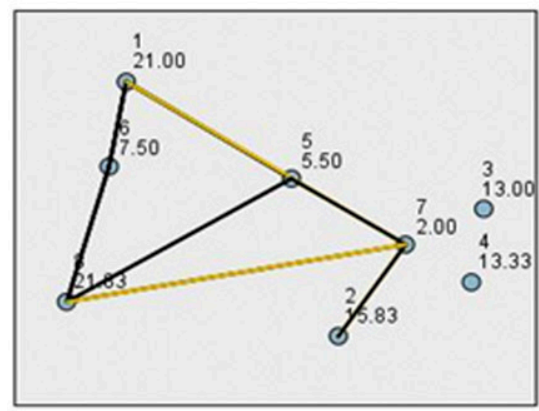

D

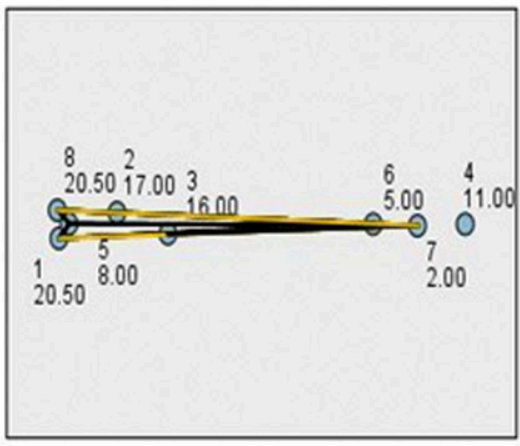

B

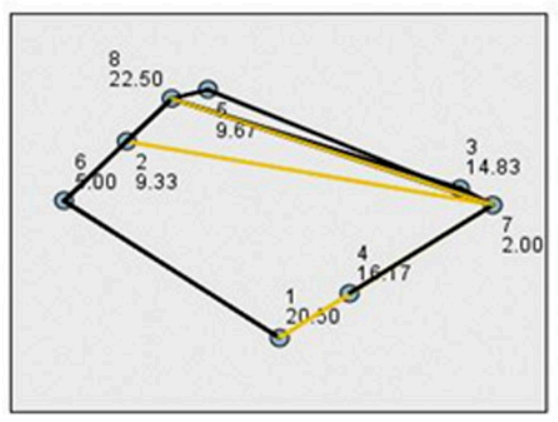

E

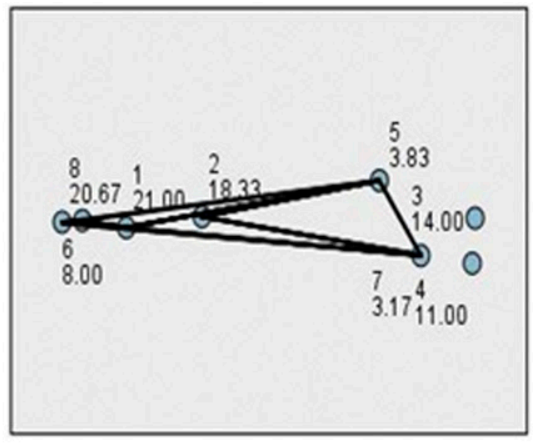

$\mathrm{C}$

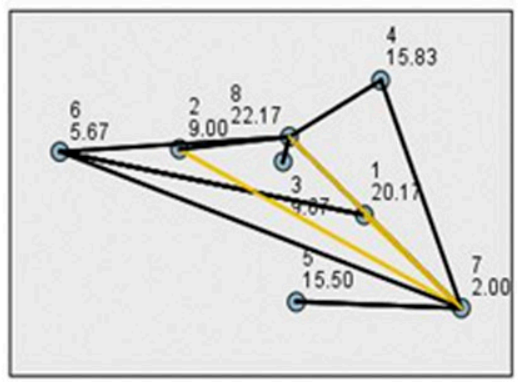

F

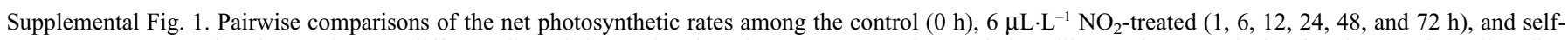
recovery european hornbeam plants at different diurnal time points based on nonparametric Kruskal-Wallis one-factor analysis of variance. The yellow line indicates a significant difference between groups after Bonferroni correction: (A) $0800 \mathrm{HR}$; (B) $1000 \mathrm{HR}$; (C) $1200 \mathrm{HR}$; (D) $1400 \mathrm{HR}$; (E) $1600 \mathrm{HR}$; and (F) $1800 \mathrm{HR}$. $1=$ control group; $2=1$-h group; $3=6$-h group; $4=12$-h group; $5=24$-h group; $6=48$-h group; $7=72$-h group; $8=$ recovery group. 


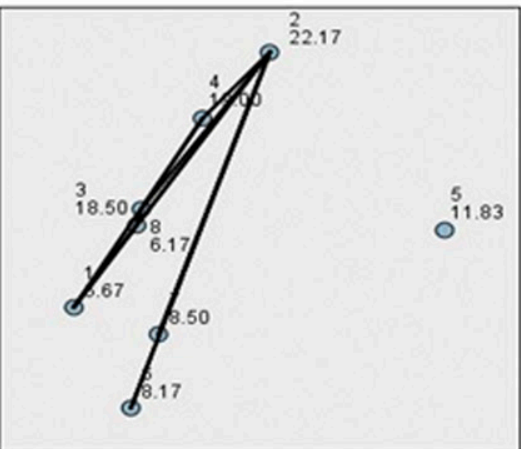

A

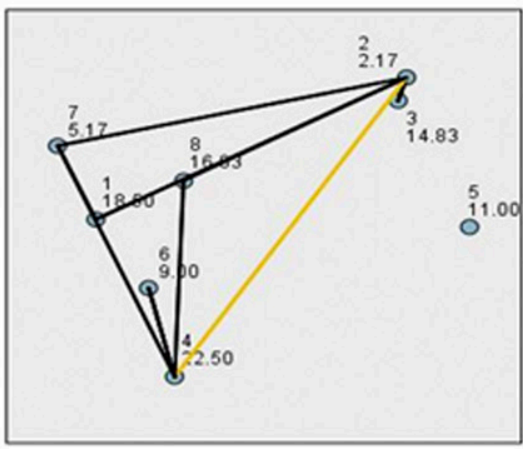

D

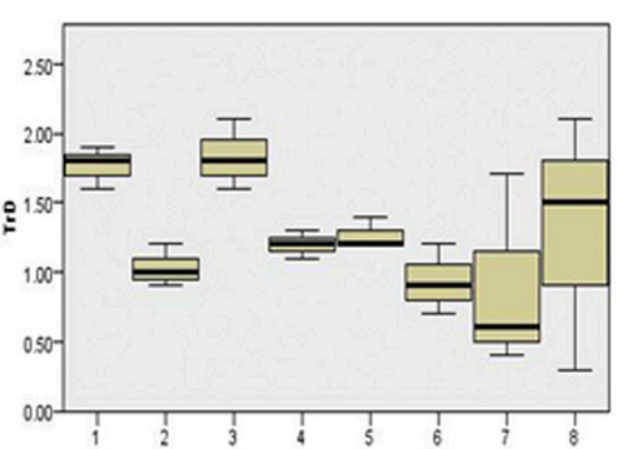

B

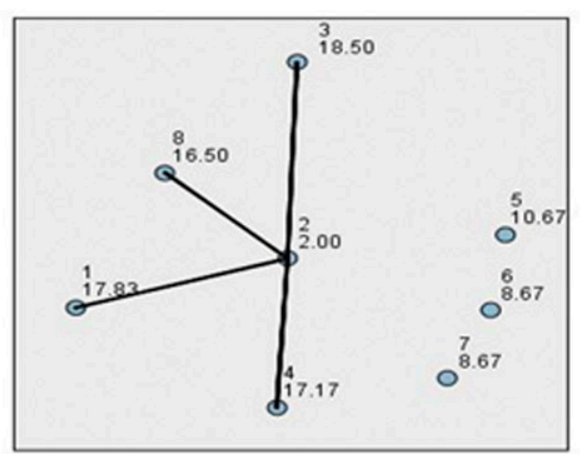

E

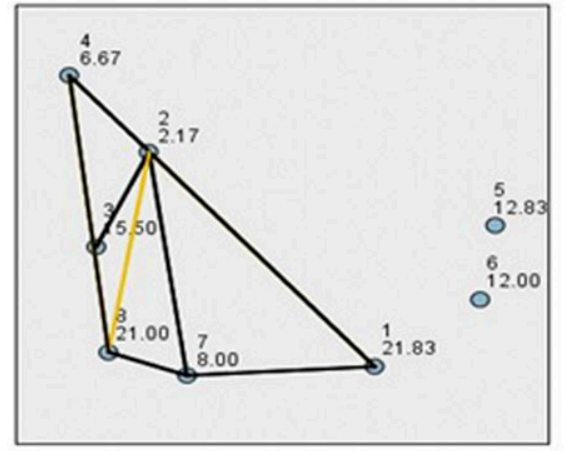

$\mathrm{C}$

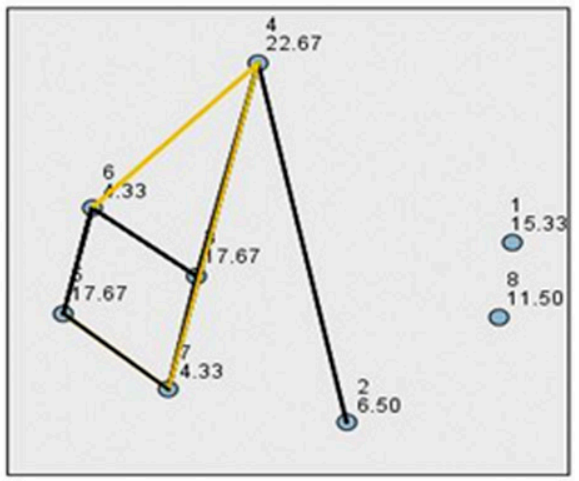

F

Supplemental Fig. 2. Pairwise comparisons of the transpiration rates among the control $(0 \mathrm{~h}), 6 \mu \mathrm{L} \cdot \mathrm{L}^{-1} \mathrm{NO}_{2}$-treated $(1,6,12,24,48$, and $72 \mathrm{~h})$, and self-recovery european hornbeam plants at different diurnal time points based on nonparametric Kruskal-Wallis one-factor analysis of variance. The yellow line indicates a significant difference between groups after Bonferroni correction: (A) $0800 \mathrm{HR}$; (B) $1000 \mathrm{HR}$; (C) $1200 \mathrm{HR}$; (D) $1400 \mathrm{HR}$; (E) $1600 \mathrm{HR}$; and (F) $1800 \mathrm{HR}$. 1 = control group; $2=1$-h group; $3=6$-h group; $4=12$-h group; $5=24$-h group; $6=48$-h group; $7=72$-h group; $8=$ recovery group. 


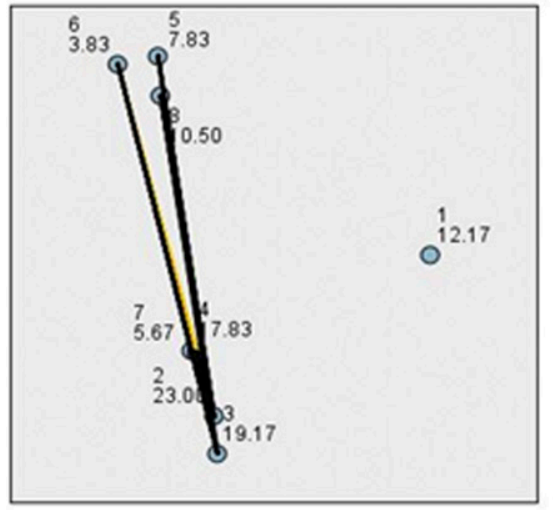

A

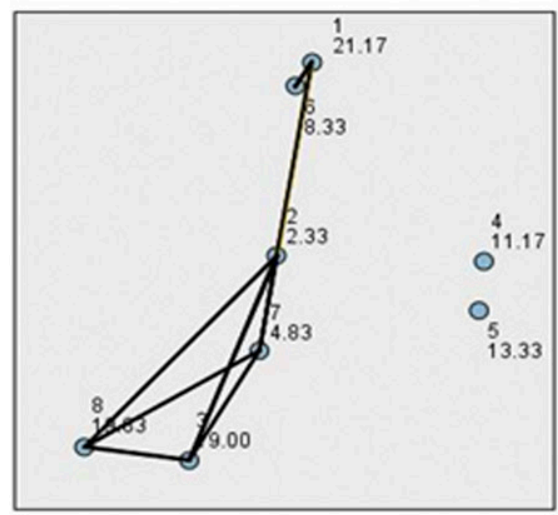

$\mathrm{D}$

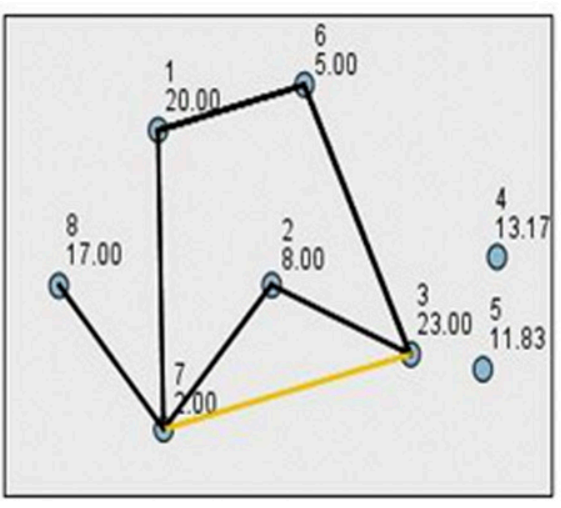

B

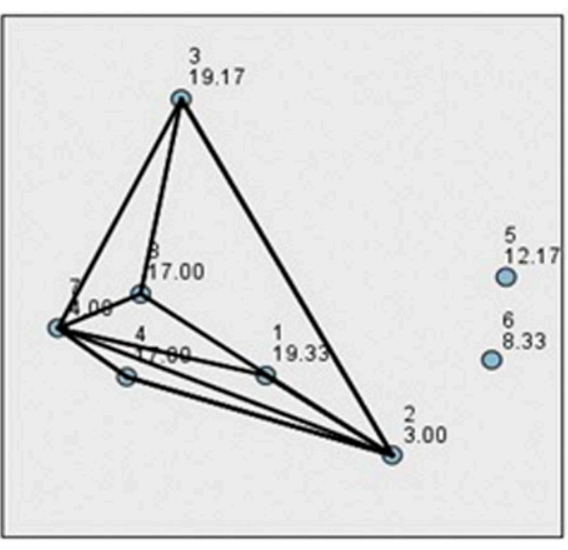

E

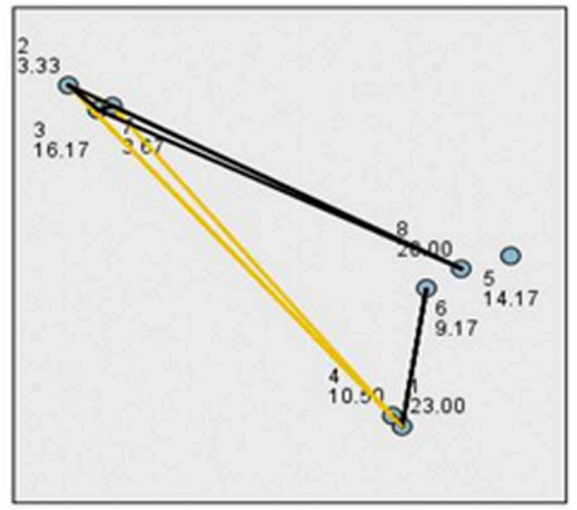

$\mathrm{C}$

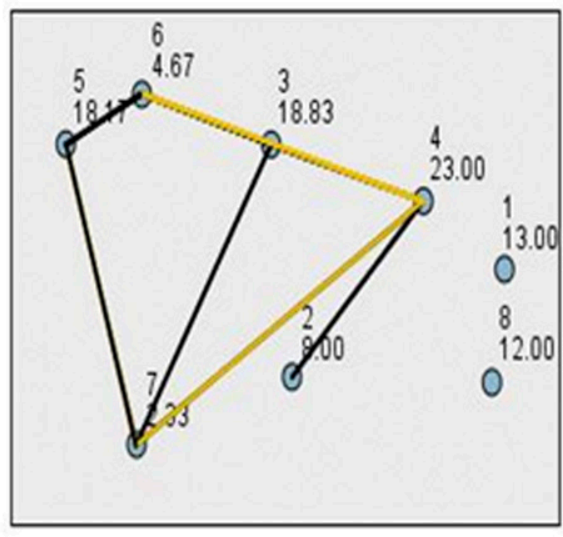

$\mathrm{F}$

Supplemental Fig. 3. Pairwise comparisons of the $g_{\mathrm{S}}$ among the control $(0 \mathrm{~h}), 6 \mu \mathrm{L} \cdot \mathrm{L}^{-1} \mathrm{NO}_{2}$-treated $(1,6,12,24,48$, and $72 \mathrm{~h})$ and self-recovery european hornbeam plants at different diurnal time points based on nonparametric Kruskal-Wallis one-factor analysis of variance. The yellow line indicates a significant difference between groups after Bonferroni correction: (A) $0800 \mathrm{HR}$; (B) $1000 \mathrm{HR}$; (C) $1200 \mathrm{HR}$; (D) $1400 \mathrm{HR}$; (E) $1600 \mathrm{HR}$; and (F) $1800 \mathrm{HR} .1$ = control group; 2 =1-h group; $3=6$-h group; $4=12$-h group; $5=24$-h group; $6=48$-h group; $7=72$-h group; $8=$ recovery group. 


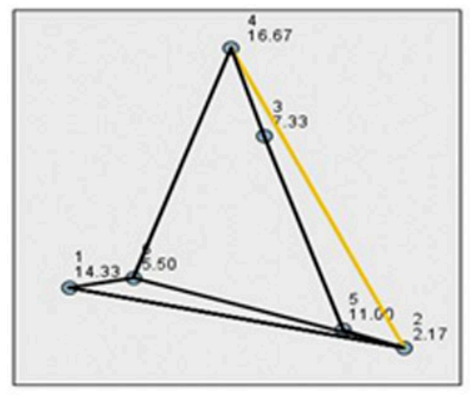

A

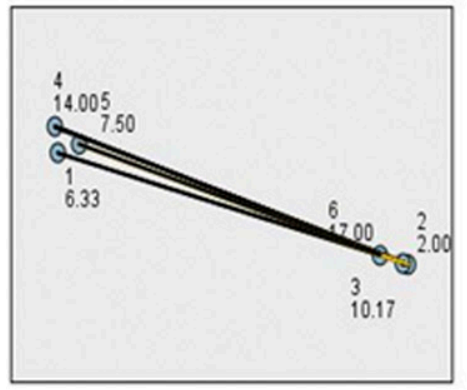

E

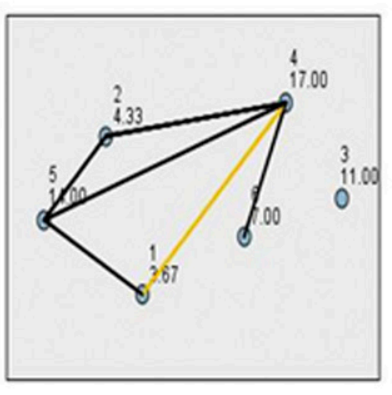

B

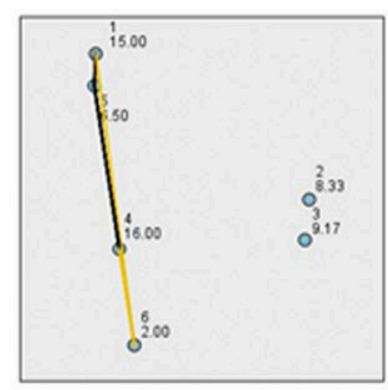

F

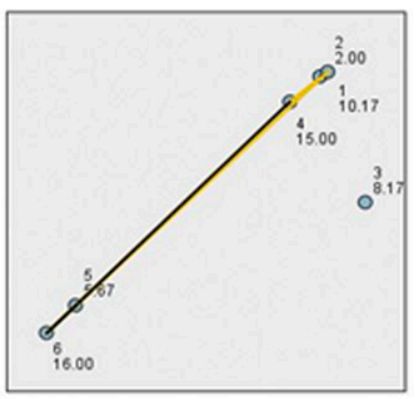

C

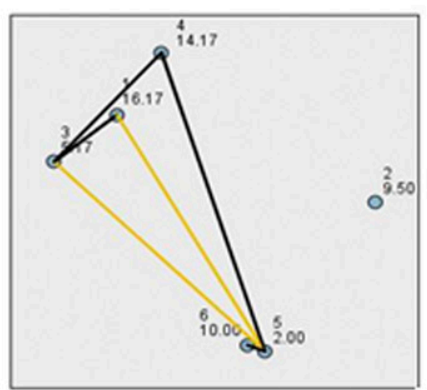

G

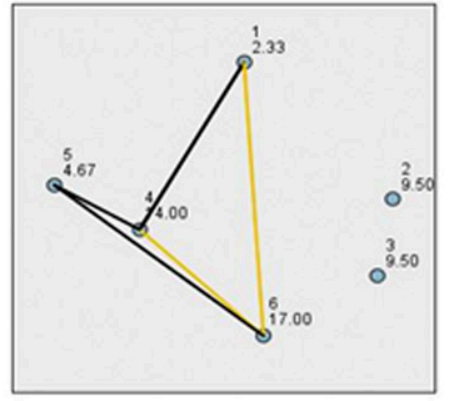

D

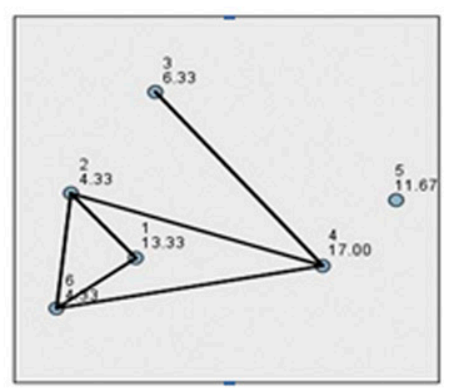

H

Supplemental Fig. 4. Pairwise comparisons of the intercellular $\mathrm{CO}_{2}$ concentrations between different diurnal time points in the same european hornbeam group. The yellow line indicates a significant difference between different diurnal time points after Bonferroni correction: (A) control group; $(\mathbf{B})$ 1-h $\mathrm{NO}_{2}$-treated group; $(\mathbf{C})$ 6-h $\mathrm{NO}_{2}$-treated group; (D) 12-h NO -treated group; (E) 24-h NO 2 -treated group; (F) 48-h NO 2 -treated group; (G) 72-h $\mathrm{NO}_{2}$-treated group; and $(\mathbf{H})$ recovery group. $1=0800 \mathrm{HR} ; 2=1000 \mathrm{HR} ; 3=1200 \mathrm{HR} ; 4=1400 \mathrm{HR} ; 5=1600 \mathrm{HR} ; 6=1800 \mathrm{HR}$. 